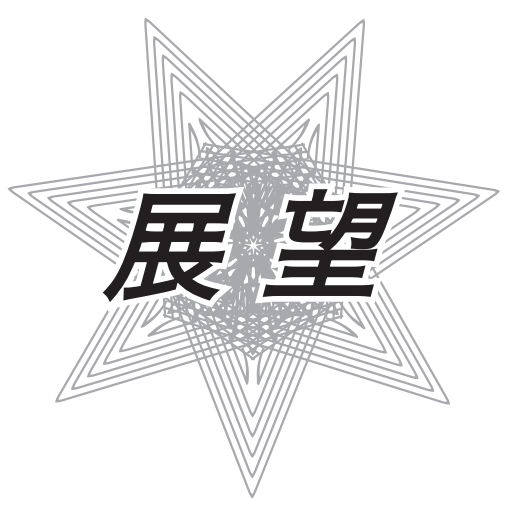

\title{
三浦 則雄
}

JAXA の小惑星探査機「はやぶさ」が宇宙探査において世界初の歴史的偉業を成し遂げたニュースは, 我々の記憶に鮮明 に残っているし，映画も最近いくつか製作されている．約 7 年間, 約 60 億 $\mathrm{km}$ という長期間, 長距離の運行を, 数々の 危機的な困難や試練を乗り越えて, 小惑星「イトカワ」から微粒子サンプルを持ち帰るという前例のない成果は奇跡的と もいえる. 多くの幸運も重なったようだが, 実際には長年積み重ねられてきた我国独自の数え切れないほどの優れた技術 の裏打ちがあったればこそといえよう. 本会に最も関係する電池技術では, 搭載された 11 個の大容量リチウムイオン二次 電池が「はやぶさ」の運行, 作動を影で強力に支援する重要な役割を果たしている. 極めて苛酷な条件下において過放電 という絶望的なトラブルに見舞われながらも, 最後まで持ちこたえて任務を成し遂げたのは何ともすごい（本誌, Vol.75, No.12, 950 (2007) 及びV Vol.76, No.7, 480 (2008) に関連論文掲載, また本会の論文賞及び技術賞を受賞).

「はやぶさ」を成功させたこのような世界に誇れる数々の技術は，なんとしても将来にわたって継続させるべきだ．幸 いにも事業仕分け結果に反して, 無事帰還の快挙により国の予算は逆に増額されたが, 一旦, 研究開発の停止や撤退をし てしまうと, 研究者, 技術者は散逸してノウハウや重要な技は途絶えてしまい, 技術の継承は困難になる. 大学において も一旦, 研究を休止したり学生間の技術の引継ぎがうまくいかないと, 再度の立ち上げが困難になったり非常に時間がか かったりした経験を打持ちの方は多いはずである．また，最近は研究資金が集中する傾向にあるが，こつこつ続けている 地道な基礎研究にも資金を分散すべきだ．すぐに成果が見える実用研究が優遇されやすいが，将来どのように役立つかは 未知数の研究分野への投資も必要だ. 自由な発想の研究が継続できなくなったら, 大学での研究の意味や価值はある意味 では失われてしまおう。.

私事で恐縮ではあるが，これまで私は朝晚， 1 分間に 100 回の腕立て伏せを 14 才から約 47 年間続けており，その総回 数は 300 万回を越える. 扔かげで若い人にも負けない腕力, 体力, 気力が自然に備わった気がする. なぜそんなことをす るのかと訊かれることも多いが, 一度始めたら止めたくない意地からだけかもしれない. だが確かに「継続は力」となっ ている，年を取れば体のあちこちは劣化するが，筋肉や脳神経は鍛えればシニアでも発達は可能というから，老骨に鞭を 打っての毎日の鍛鍊の継続も意味を持つ.

世界一の強度と美しさを誇る日本刀の刀工技術は，主に刀鍛冶と研師による伝統的な日 本の優れた匠の技として約千年間にわたって，人から人へと途絶えることなく継承されて きた．刀鍛冶は鉄の成分を微妙に調整しながら折り返し鍛錬を幾度となく繰り返し，研師 は一ヶ月近く研ぎ上げることにより，飛んでくる弾丸をも真っ二つにする威力を持つとと もに，世界最高の美術品としての日本刀に仕上げるという。このような優れた伝統的な匠 の技はわが国には数限りなく存在する．また，近年の新幹線や高速リニア鉄道，自動車や 電化製品にしてもその技術の高さに起因する高品質さ故に世界中から確固たる信頼を勝ち 得てきた．これらも研究者や技術者らの技術の積み重ねや承継が行われてきた成果である.

80 年の長い歴史と伝統を持つ本会は, 先達の努力と智慧の継続・継承の上に成り立つ ており, 会員数も年々増加して公益法人化後には 5 千人を越える. 本会では, 多くの専門 委員会, 技術想談会, 支部がそれぞれ独自の活動を活発に継続することにより, 全体の発 展につなげるという他学会とは異なった特質を堅持してきた. 公益法人化後もこのような 独自の特徴をしっかり「継続」させることで, 本会全体がさらなる大きな「力」をつけ, これからも益々発展することを期待したい.

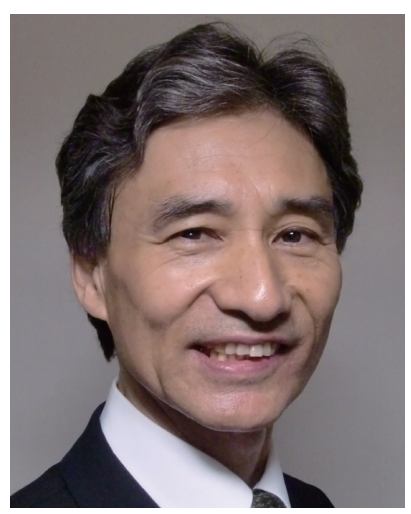

Norio MIURA

本会平成 23,24 年度副会長 九州大学産学連携センター 教授 